American Journal of Applied Sciences 5 (4): 392-404, 2008

ISSN 1546-9239

(C) 2008 Science Publications

\title{
Manganese Uptake By Facultative and Obligate Wetland Plants Under Laboratory Conditions
}

\author{
A. E. Ghaly, A. Snow and M. Kamal \\ Department of Process Engineering and Applied Science \\ Dalhousie University, Halifax, Nova Scotia, Canada
}

\begin{abstract}
The effect of initial concentrations of manganese on the overall removal efficiency of $\mathrm{Mn}$ by wool grass, soft rush, broad leaved cattail and soft stem bulrush plants was investigated under laboratory conditions. The translocation of $\mathrm{Mn}$ in the roots, stems, leaves and flowers of each plant species was determined and the fraction of Mn removed by precipitation was calculated. The overall manganese removal efficiencies of the system during the first period were 97.66, 94.09, 98.51 and $98.44 \%, 90.94,95.47,96.83$ and $85.51 \%$ and $92.65,75.55,97.56$ and $75.55 \%$ which decreased to $82.22,89.94,95.26$ and $95.85 \%, 87.78,91.85,90.49$ and $84.16 \%$ and $38.88,61.61,31.54$ and 71.64 $\%$ by the end (after 72 days) of the experiment for soft stem bulrush, wool grass, soft rush and cattail in the compartments receiving tolerance concentration, landfill leachate and the control, respectively. The removal of manganese was a function of the initial Mn concentration and the higher the initial concentration the higher the removal efficiency. The results showed the addition of manganese (from wastewater) to the soil by precipitation at average rates of 2.17 and $17.19 \mathrm{mg} / \mathrm{kg} / \mathrm{day}, 2.11$ and 15.75 $\mathrm{mg} / \mathrm{kg} / \mathrm{day}, 1.71$ and $15.86 \mathrm{mg} / \mathrm{kg} / \mathrm{day}$ and 1.17 and $15.29 \mathrm{mg} / \mathrm{kg} / \mathrm{day}$ for soft stem bulrush, wool grass, soft rush and cattail in the compartments receiving landfill leachate and tolerance concentration, respectively. The leaves of wool grass, soft rush and cattail accumulated significantly greater concentrations of manganese than the roots with translocation factors $>1$ indicating high translocation of $\mathrm{Mn}$ from root to shoot for the control, landfill leachate and tolerance concentration, respectively.
\end{abstract}

Keywords: $\quad$ manganese, wool grass, soft rush, soft stem bulrush, cattail, landfill leachate, tolerance concentration

\section{INTRODUCTION}

Living plants can be compared to solar driven pumps which can extract and concentrate elements from their environment. From soil and water, all plants have the ability to accumulate heavy metals such as $\mathrm{Mg}, \mathrm{Fe}, \mathrm{Mn}, \mathrm{Zn}, \mathrm{Cu}$ and $\mathrm{Mo}$ which are essential for their growth and development ${ }^{[1,2]}$. Certain plants also have the ability to accumulate heavy metals which have no known biological function including $\mathrm{Cd}, \mathrm{Cr}, \mathrm{Pb}, \mathrm{Co}$, $\mathrm{Ag}$, Se and $\mathrm{Hg}^{[3,4]}$. However, excessive accumulation of essential and nonessential heavy metals can be toxic to most plants.

The ability to both tolerate elevated levels of heavy metals and accumulate them in very high concentrations has evolved in a number of different plant species ${ }^{[5]}$. Plants distribute metals internally in many different ways. They may localize selected metals mostly in roots and stems, or they may accumulate and store other metals in nontoxic form for latter distribution and use. A mechanism of tolerance or accumulation in some plants apparently involves binding potentially toxic metals at cell walls of roots and leaves away from sensitive sites within the cell or storing them in a vacuolar compartment ${ }^{[6,7]}$.

Wetlands have been used to treat heavy metal contaminated wastewaters from municipal, agricultural and industrial sources. In wetlands, several processes combine to provide overall treatment including: sedimentation and filtration of solids, (b) gasification of volatile substances, (c) chemical precipitation, (d) ion exchange, and (e) plant uptake of metals ${ }^{[8]}$. Wetland vegetation is extremely important for the nutrient transformations and transfers because it plays a key role in the cycling and temporary storage of many substances and provides habitat and energy sources to maintain a diverse microbial population in the sediments ${ }^{[9,10]}$. It is, therefore, important to understand

Corresponding author: $\quad$ A. E. Ghaly, Professor, Department of Process Engineering and Applied Science, Dalhousie University, Halifax, Nova Scotia, Canada Email:Abdel.ghaly@dal.ca; Tel: (902) 494-6014; Fax: (902) 420-7639 
the uptake and storage of metals in various parts of wetland plants.

There are five categories of wetland plants: (a) obligate wetland plants which are found in wetlands 99 $\%$ of the time, (b) facultative wetland plants which are found in wetlands $67-99 \%$ of the time, (c) facultative plants which are found in wetlands or non-wetlands 33$67 \%$ of the time, (d) facultative upland plants which are found in wetlands $1-33 \%$ of the time and (e) obligate upland plants which occur in non-wetlands $>99$ $\%$ of the time ${ }^{[11]}$. The aim of this study was to assess the performance of selective facultative and obligate wetland plants for the removal of $\mathrm{Mn}$ from contaminated wastewater. The specific objectives were: (a) to investigate the effect of initial concentrations of manganese on the overall removal efficiency of Mn by obligate and facultative wetland plants, (b) to determine the translocation of $\mathrm{Mn}$ in the different parts of each plant species (root, stem, leaves and flower), and (c) to determine the fraction of Mn removed by precipitation.

\section{EXPERIMENTAL APPARATUS}

The experimental setup shown in Fig. 1 consists of holding tanks and lighting and aeration systems.

Holding Tanks: Four boxes were constructed from 2.5 $\mathrm{cm}$ thick plywood. Each box $(60 \times 120 \times 80 \mathrm{~cm})$ was divided into three compartments $(30 \times 60 \times 80 \mathrm{~cm}$ each) and each compartment contained a holding tank.

Lighting System: The light was provided by an artificial lighting system $\left(625\right.$ hectolux/7200 $\left.\mathrm{cm}^{2}\right)$ and was similar to the natural light required for wetland plants. Each lighting unit consisted of eight light bulbs (six 34 watts cool white fluorescent bulbs and two Grolux 40 watts bulbs) of $122 \mathrm{~cm}$ in length. The lighting system was placed on the top of each box using wooden supports in such a way that it gave a space of $140 \mathrm{~cm}$ clearance between the light bulbs and the water surface in the box. This space was chosen to achieve good air circulation and provide the heat and light that were required for plant growth. The lights were controlled by a timer, which was set to provide 16 hours of light per box per day and to maintain a temperature difference between the soil and the above ground part of $15^{\circ} \mathrm{C}^{[12]}$.

Aeration System: An aeration unit was installed in the bottom of each compartment to provide oxygen for the plants. The air traveled from the main laboratory supply to a manifold with twelve outlets. Each outlet was

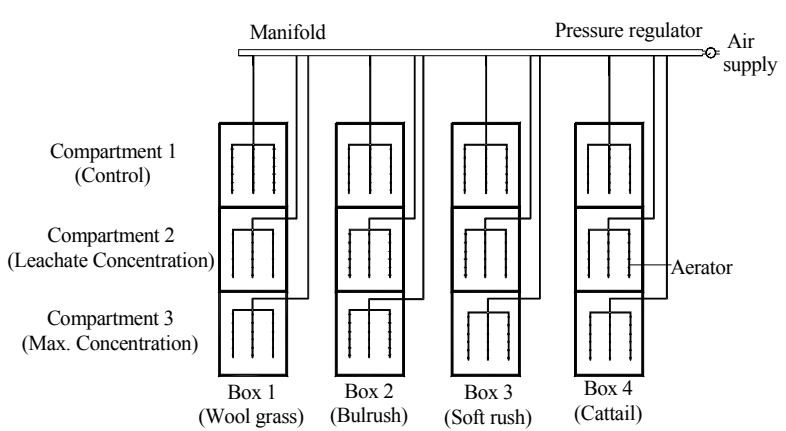

(a) Holding Tanks

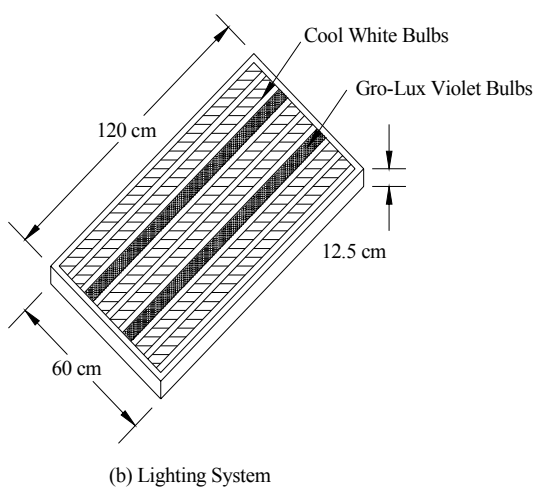

Fig. 1: Experimental apparatus

connected to a pressure regulator (Model 129121/510, ARO, Bryan, Ohio), which was connected to an aerator located in each compartment. Each aerator consisted of a main tube (26.5 cm long) with three perforated stainless steel laterals $(30 \mathrm{~cm}$ in length and $0.6 \mathrm{~cm}$ in diameter) coming off it at right angles to the main. Tygon tubing of $0.75 \mathrm{~cm}$ outside diameter was used to connect the main air supply, manifold and aeration unit. The pressure regulator was adjusted at 0.068 atm during the whole experimental period to give an aeration rate of $7 \mathrm{~cm}^{3} / \mathrm{min}$.

\section{EXPERIMENTAL PROCEDURES}

Wetland Plants: Two facultative (wool grass and soft rush) and two obligate (broad-leaved cattail and soft stem bulrush) wetland plant species were used in the study (Fig. 2). The selection of these plants was based on their dominance in the constructed wetland ${ }^{[13]}$. Both soft rush and soft stem bulrush have been listed in many references as both obligate and facultative wetland plants. These wetland plants were obtained from Environmental Concern Inc., St. Michaels, Maryland, USA. 


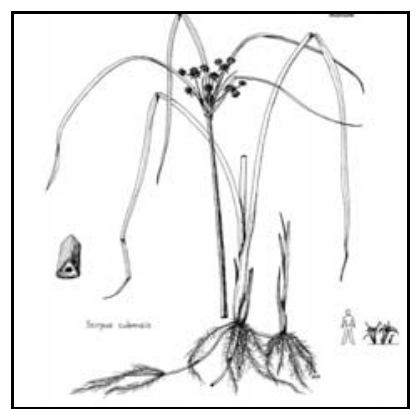

(a) Wool grass

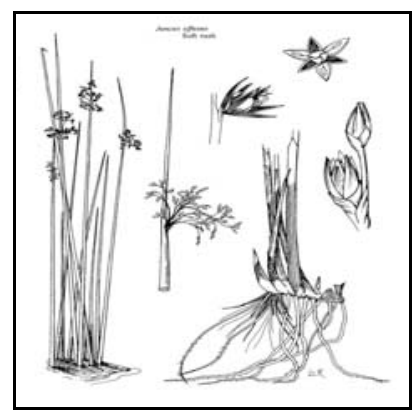

(b) Soft rush

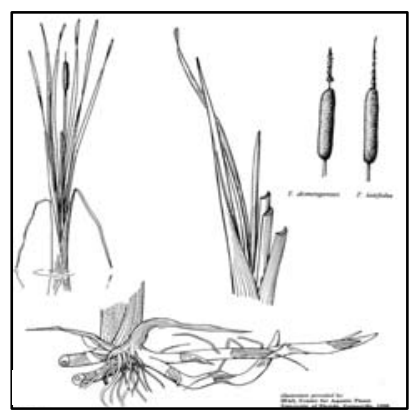

(c) Broad-leaved cattail

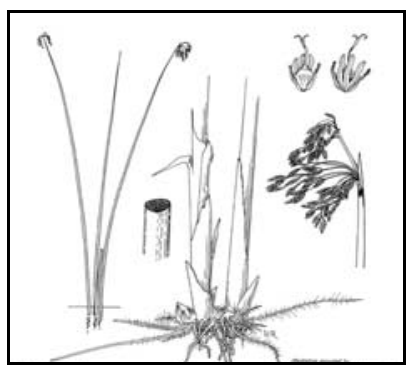

(d) Soft stem bulrush

Fig. 2: Plant species used in the experiments

Contaminant Preparation: The plants were supplied with nutrients using a fertilizer (20-20-20 Plant-Prod, Plant Products Co. Ltd., Brampton,, Ontario) (817 mg daily basis. of fertilizer per $1 \mathrm{~L}$ of water). Manganous sulfate $\left(\mathrm{MnSO}_{4} \cdot \mathrm{H}_{2} \mathrm{O}\right)$ was used as a contaminant supply of manganese. This compound was purchased as a reagent grade chemical from Fisher Scientific, Ottawa, Ontario. Manganese concentrations were selected to: (a) simulate concentrations in the influent of a constructed wetland $^{[14]}$ and (b) replicate the highest tolerance reported in the literature ${ }^{[9]}$. $\mathrm{MnSO}_{4} \cdot \mathrm{H}_{2} \mathrm{O}$ was dissolved in distilled water to achieve the appropriate contaminant level. The final concentrations of manganese used in this experiment are presented in Table 1.

Experimental Protocol : A $10 \mathrm{~cm}$ layer of large gravel $(1.25 \mathrm{~cm}$ average nominal size) was placed in each compartment to facilitate the collection of drainage water. A $35.5 \mathrm{~cm}$ long drainage tube, with holes in the lower $10 \mathrm{~cm}$ end, was placed vertically in each compartment. The drainage tube was connected to a wet vacuum pump (Bulldog 700, Shop-Vac Canada Ltd., Burlington, Ontario) to ensure complete drainage of water before introducing the next batch of contaminated water. Soil was used as a supporting media for the plants. It was placed into each compartment in layers (approximately $10 \mathrm{~cm}$ thick) and lightly compacted to remove excessive voids within the soil structure. One box (three compartments) was used for each plant species. About 8 plants $(20-30 \mathrm{~cm}$ tall) were placed in each of the three compartments in each box. The start up procedure for growing wetland plants in a closed system followed that described by Mills ${ }^{[12]}$. The water level in each compartment was maintained below the root system of the plants while keeping the soil around the root system moist at all times. The plants were sprayed with the insecticide Malathion 500EC (The Solaris Group, Mississauga, Ontario) every week to control the spread of aphids in the system. The dilution rate recommended by the manufacture was followed $(2.5 \mathrm{ml}$ of Malathion was mixed in $1 \mathrm{~L}$ of water). After the startup period of 4 weeks, the experiment was run for 72 days.

The first compartment in each box was used as a control and received $30 \mathrm{~L}$ of tap water containing fertilizer, the second compartment received $30 \mathrm{~L}$ of contaminated water containing fertilizer and a Mn concentration similar to that received by a constructed wetland and the third compartment received $30 \mathrm{~L}$ of contaminated water containing fertilizer and a Mn concentration similar to that reported in the literature as the highest tolerance level for the four plants. The wastewater was changed every 9 days to simulate the retention time of the water in the constructed wetland ${ }^{[13]}$.. The insecticide was sprayed every week and the growth of individual plants was observed on a 
Am. J. Applied Sci., 5 (4): 392-404, 2008

Table 1: Concentrations of manganese $(\mathrm{mg} / \mathrm{L})$ in the water

\begin{tabular}{lrrr}
\hline Element & Control & Landfill Leachate & $\begin{array}{c}\text { Tolerance } \\
\text { Concentration }\end{array}$ \\
\hline Nutrient & & & \\
Potassium & 163.40 & 163.40 & 163.40 \\
Nitrogen & 163.40 & 163.40 & 163.40 \\
Phosphorus & 163.40 & 8.17 & 163.40 \\
EDTA & 8.17 & 0.16 & 0.17 \\
Boron & 0.16 & 8.60 & 123.21 \\
Sulfur & ----- & & \\
Heavy Metals & & 0.82 & 0.82 \\
Iron & 0.82 & 2.21 & 15.41 \\
Manganese & 0.41 & 0.41 & 0.41 \\
Copper & 0.41 & 0.41 & 0.41 \\
Zinc & 0.41 &
\end{tabular}

Sampling and Analyses: Water, soil and plant samples were collected from all compartments at 9 day intervals. The water samples $(100 \mathrm{~mL})$ were withdrawn using a $25 \mathrm{~mL}$ wide tip pipette and analyzed for $\mathrm{Mn}$. The soil samples $(50 \mathrm{~g})$ were collected from the middle of each compartment and analyzed for Mn. The plant samples (root, stem, leaf, and flower) were analyzed for $\mathrm{Mn}$. The plant and soil samples were dried in a convection oven for 24 hours at $45^{\circ} \mathrm{C}$. After drying, the plant and soil samples were ground and digested with hydrochloric-nitric-hydrofluric-perchloric acids $(30+10+10+5 \mathrm{~mL} / \mathrm{g}$ sample) in a closed vessel at a temperature of $100{ }^{\circ} \mathrm{C}$. The $\mathrm{Mn}$ concentration was determined using an atomic absorption spectometer (Varion SpectrAA, Model Number: 55B, Varion, Mulgrave, Victoria, Australia).

Statistical Analysis: Analysis of variance (ANOVA) was performed on the water, soil and plant data using SAS System, 5th Ed. (SAS Institute Inc., Cary, North Carolina). Duncan Multiple range tests were also performed on the data to test the differences among the levels of each factor.

\section{RESULTS AND DISCUSSIONS}

Water: The manganese concentrations in the effluent waters and the manganese removal efficiencies for bulrush, wool grass, soft rush and cattail are shown in Table 2. The results of the analysis of variance performed on the manganese removal efficiencies are shown in Tables 3 and 4.
The manganese concentration in the effluent from the soft stem bulrush compartment at the end of the 9 day retention period ranged from 0.20 to $0.30 \mathrm{mg} / \mathrm{L}$, from 0.36 to $2.74 \mathrm{mg} / \mathrm{L}$ and from 0.03 to $0.25 \mathrm{mg} / \mathrm{L}$ for landfill leachate, tolerance concentration and control, respectively. The concentration of manganese in the effluent from the wool grass compartment at the end of the 9 day retention period ranged from 0.10 to 0.18 $\mathrm{mg} / \mathrm{L}$, from 0.91 to $1.55 \mathrm{mg} / \mathrm{L}$ and from 0.10 to 0.36 $\mathrm{mg} / \mathrm{L}$ for the landfill leachate, tolerance concentration and control, respectively. The manganese concentration in the effluent from the soft rush compartment at the end of the 9 day retention period ranged from 0.07 to $0.21 \mathrm{mg} / \mathrm{L}$, from 0.23 to $0.73 \mathrm{mg} / \mathrm{L}$ and from 0.02 to $0.28 \mathrm{mg} / \mathrm{L}$ for the landfill leachate, tolerance concentration and control, respectively. The manganese concentration in the effluent from the cattail compartment at the end of the 9 day retention period ranged from 0.13 to $0.35 \mathrm{mg} / \mathrm{L}$, from 0.24 to $0.64 \mathrm{mg} / \mathrm{L}$ and from 0.10 to $0.13 \mathrm{mg} / \mathrm{L}$ for the landfill leachate, tolerance concentration and control, respectively.

The ANOVA results showed that the plant type, time and $\mathrm{Mn}$ initial concentration have significant effects on the Mn removal efficiency $(\mathrm{P}=0.0001)$. The results also showed significant interactions $(\mathrm{P}=0.0001)$ between these parameters. The results of Duncan's Multiple Range test showed that the four plants used in this study were significantly different from one another in their ability to remove manganese and the three levels of initial manganese concentrations in the wastewater were significantly different from one another at a $95 \%$ confidence level. However, the average removal efficiency during the periods 4,5 and 6 were not significantly different from one another at a $95 \%$ confidence level.

The overall manganese removal efficiencies of the system during the first period were 97.66, 94.09, 98.50 and $98.44 \%$ and $90.94,95.47,96.83$ and $85.51 \%$ which decreased to $82.22,89.94,95.26$ and $95.84 \%$ and $87.77,91.85,90.49$ and $84.15 \%$ by the end (after 72 days) of the experiment for soft stem bulrush, wool grass, soft rush and cattail in the compartments receiving tolerance concentration and landfill leachate, respectively (Figure 4). The results showed that the compartments receiving landfill leachate had overall manganese removal efficiencies lower than those of the compartments receiving the tolerance concentration. This indicates that the removal of manganese was a function of the initial concentration and the higher the initial concentration the higher the removal efficiency. Kamal et al. ${ }^{[15]}$ reported similar results for $\mathrm{Fe}$ and $\mathrm{Hg}$. 
Am. J. Applied Sci., 5 (4): 392-404, 2008

Table 2: Manganese effluent concentration and removal efficiency

\begin{tabular}{|c|c|c|c|c|c|c|c|c|c|}
\hline \multirow[b]{2}{*}{ Time } & \multirow[b]{2}{*}{ Treatment } & \multicolumn{2}{|c|}{ Bulrush } & \multicolumn{2}{|c|}{ Wool grass } & \multicolumn{2}{|c|}{ Soft rush } & \multicolumn{2}{|c|}{ Cattail } \\
\hline & & $\begin{array}{c}\mathrm{EC} \\
(\mathrm{mg} / \mathrm{L})\end{array}$ & $\begin{array}{l}\mathrm{RE} \\
(\%)\end{array}$ & $\begin{array}{c}\mathrm{EC} \\
(\mathrm{mg} / \mathrm{L})\end{array}$ & $\begin{array}{l}\mathrm{RE} \\
(\%)\end{array}$ & $\begin{array}{c}\mathrm{EC} \\
(\mathrm{mg} / \mathrm{L})\end{array}$ & $\begin{array}{l}\mathrm{RE} \\
(\%)\end{array}$ & $\begin{array}{c}\mathrm{EC} \\
(\mathrm{mg} / \mathrm{L})\end{array}$ & $\begin{array}{l}\mathrm{RE} \\
(\%)\end{array}$ \\
\hline \multirow[t]{3}{*}{9} & Tolerance & $0.36(0.03)$ & 97.66 & $0.91(0.06)$ & 94.09 & $0.23(0.02)$ & 98.51 & $0.24(0.02)$ & 98.44 \\
\hline & Leachate & $0.20(0.01)$ & 90.94 & $0.10(0.01)$ & 95.47 & $0.07(.005)$ & 96.83 & $0.32(0.02)$ & 85.51 \\
\hline & Control & $0.03(0.002)$ & 92.65 & $0.10(.002)$ & 75.55 & $0.10(0.001)$ & 97.56 & $0.10(0.007)$ & 75.55 \\
\hline \multirow[t]{3}{*}{18} & Tolerance & $0.36(0.02)$ & 97.66 & $1.10(0.07)$ & 92.86 & $0.33(0.02)$ & 97.86 & $0.55(0.04)$ & 96.43 \\
\hline & Leachate & $0.21(0.01)$ & 90.49 & $0.10(0.01)$ & 95.47 & $0.12(0.01)$ & 94.56 & $0.28(0.02)$ & 97.32 \\
\hline & Control & $0.05(0.003)$ & 87.78 & $0.18(.012)$ & 55.99 & $0.02(0.001)$ & 95.11 & $0.10(0.006)$ & 75.55 \\
\hline \multirow[t]{3}{*}{27} & Tolerance & $0.63(0.03)$ & 95.91 & $1.37(0.08)$ & 91.11 & $0.43(0.03)$ & 97.21 & $0.55(0.03)$ & 96.43 \\
\hline & Leachate & $0.30(0.02)$ & 86.41 & $0.10(0.01)$ & 95.47 & $0.14(0.01)$ & 93.66 & $0.13(0.01)$ & 94.11 \\
\hline & Control & $0.08(0.005)$ & 80.44 & $0.24(.014)$ & 41.32 & $0.04(0.002)$ & 90.22 & $0.11(0.007)$ & 72.37 \\
\hline \multirow[t]{3}{*}{36} & Tolerance & $0.80(0.06)$ & 94.81 & $1.37(0.10)$ & 91.11 & $0.63(0.05)$ & 95.91 & $0.73(0.06)$ & 95.26 \\
\hline & Leachate & $0.29(0.02)$ & 86.87 & $0.14(0.01)$ & 93.66 & $0.21(0.01)$ & 90.49 & $0.18(0.01)$ & 91.85 \\
\hline & Control & $0.13(0.010)$ & 68.22 & $0.30(.024)$ & 26.65 & $0.08(0.006)$ & 80.44 & $0.13(0.010)$ & 67.97 \\
\hline \multirow[t]{3}{*}{45} & Tolerance & $0.70(0.05)$ & 95.45 & $1.01(0.07)$ & 93.45 & $0.65(0.05)$ & 95.78 & $0.46(0.03)$ & 97.01 \\
\hline & Leachate & $0.26(0.02)$ & 88.23 & $0.16(0.01)$ & 92.75 & $0.20(0.02)$ & 90.49 & $0.13(0.01)$ & 94.11 \\
\hline & Control & $0.15(0.010)$ & 63.32 & $0.36(.025)$ & 11.98 & $0.11(0.007)$ & 73.11 & $0.13(0.095)$ & 97.23 \\
\hline \multirow[t]{3}{*}{54} & Tolerance & $2.19(0.11)$ & 85.78 & $1.28(0.06)$ & 91.69 & $0.73(0.04)$ & 95.26 & $0.55(0.03)$ & 96.43 \\
\hline & Leachate & $0.30(0.02)$ & 86.41 & $0.15(0.01)$ & 93.21 & $0.21(0.01)$ & 90.49 & $0.28(0.01)$ & 87.32 \\
\hline & Control & $0.20(0.010)$ & 51.10 & $0.18(.009)$ & 55.01 & $0.15(0.007)$ & 63.33 & $0.11(0.005)$ & 73.35 \\
\hline \multirow[t]{3}{*}{63} & Tolerance & $2.58(0.17)$ & 83.25 & $1.10(0.07)$ & 92.86 & $0.63(0.04)$ & 95.91 & $0.55(0.04)$ & 96.43 \\
\hline & Leachate & $0.26(0.02)$ & 88.23 & $0.16(0.01)$ & 92.76 & $0.20(0.01)$ & 90.49 & $0.13(0.01)$ & 94.12 \\
\hline & Control & $0.20(0.013)$ & 51.10 & $0.17(.011)$ & 58.43 & $0.24(0.015)$ & 41.32 & $0.12(0.007)$ & 71.64 \\
\hline \multirow[t]{3}{*}{72} & Tolerance & $2.74(0.16)$ & 82.22 & $1.55(0.09)$ & 89.94 & $0.73(0.04)$ & 95.26 & $0.64(0.04)$ & 95.85 \\
\hline & Leachate & $0.27(0.02)$ & 87.78 & $0.18(0.01)$ & 91.85 & $0.21(0.01)$ & 90.49 & $0.35(0.02)$ & 84.16 \\
\hline & Control & $0.25(0.015)$ & 38.88 & $0.16(.009)$ & 61.61 & $0.28(0.017)$ & 31.54 & $0.12(0.007)$ & 71.64 \\
\hline
\end{tabular}

The values are the average of 3 replicates with a coefficient of variation in the ranges of $1.0-6.0 \%$.

Initial tolerance concentration $=15.41 \mathrm{mg} / \mathrm{L}$.

Initial landfill leachate concentration $=2.21 \mathrm{mg} / \mathrm{L}$.

Initial control concentration $=0.41 \mathrm{mg} / \mathrm{L}$.

() standard deviation

EC effluent concentration

RE removal efficiency

The manganese removal efficiencies obtained in this study are comparable to those reported in the literature. Groudeva et al. ${ }^{[16]}$ conducted a study to determine the ability of a constructed wetland planted (Typha latifolia, Typha angustifolia, Phragmites communis, Scirpus lacustris and Juncus spp.) to treat waters contaminated with crude oil and toxic heavy metals and reported initial manganese concentrations in the water of $0.64-3.74 \mathrm{mg} / \mathrm{L}$ and effluent manganese concentrations of $<0.5 \mathrm{mg} / \mathrm{L}$. Mitchell and Karathanasis $^{[17]}$ conducted a study to examine metal removal efficiencies from a metal chloride enriched wastewater by simulated constructed wetlands planted with soft stem bulrush and cattail and found that the average retention of manganese was $24 \%$ over a 12 week period. Brodie ${ }^{[18]}$ evaluated manganese removal efficiencies of aerobic constructed wetlands planted with cattail, wool grass, sedge and rush treating drainage from coal mining and processing facilities and coal fired power plants and reported that manganese removal efficiencies were in the range of $60-96 \%$.

Ye et al. ${ }^{[9]}$ stated that phytoremediation mechanisms prove relatively insignificant, accounting for approximately $1-4 \%$ of manganese removal in wetlands. Previous studies ${ }^{[19-23]}$ showed that constructed wetlands are less successful in removing manganese. 
Skousen et al. ${ }^{[24]}$ reported that oxidized manganese does not readily precipitate unless the $\mathrm{pH}$ of water is at least 7.0 , with precipitation most commonly occurring in waters with $\mathrm{pHs}$ greater than 10.0. In addition, manganese oxidation is sensitive to the presence of $\mathrm{Fe}^{2+}$ which can prevent or even reverse manganese oxidation $^{[24]}$. In the current study, the $\mathrm{pH}$ of the wastewaters was not acidic, hence removal of Mn via precipitation took place in the system. The soil analysis results showed increased $\mathrm{Mn}$ concentrations. BCMELP $^{[25]}$ reported that the most effective removal mechanism for manganese in treatment wetland systems is settling, as 90 to $95 \%$ of total waterborne manganese binds to particulate matter.

Table 3: Analysis of variance of the manganese removal efficiency

\begin{tabular}{lrrrrc}
\hline Source & DF & \multicolumn{1}{c}{ SS } & \multicolumn{1}{c}{ MS } & F-Value & P \\
\hline Total & 191 & 67075.38 & 351.18 & & \\
Model & 95 & 66831.56 & 703.49 & 276.99 & 0.0001 \\
$\quad$ Plant Type (P) & 3 & 2552.19 & 850.73 & 334.97 & 0.0001 \\
$\quad$ Time (T) & 7 & 4719.77 & 674.25 & 265.48 & 0.0001 \\
$\quad$ Concentration & 2 & 36853.10 & 18426.55 & 7255.27 & 0.0001 \\
(C) P T & 21 & 5011.22 & 238.63 & 93.96 & 0.0001 \\
$\quad$ P x C & 6 & 4693.16 & 782.19 & 307.98 & 0.0001 \\
T x C & 14 & 5121.54 & 365.82 & 144.04 & 0.0001 \\
$\quad$ P x T x C & 42 & 7880.57 & 187.63 & 73.88 & 0.0001 \\
Error & 96 & 243.82 & 2.54 & & \\
\hline $\mathrm{R}^{2} \quad=0.99$ & & & & & \\
CV $\quad=1.91 \%$ & & & & &
\end{tabular}

Table 4: Differences among the plant type, periods and initial

\begin{tabular}{|c|c|c|c|}
\hline Parameter & $\begin{array}{c}\text { Number of } \\
\text { Observations }\end{array}$ & $\begin{array}{l}\text { Mn Removal } \\
\text { Efficiency }\end{array}$ & $\begin{array}{c}\text { Duncan } \\
\text { Grouping }\end{array}$ \\
\hline \multicolumn{4}{|l|}{ Plant Type } \\
\hline Soft stem & 48 & 81.36 & A \\
\hline bulrush & 48 & 77.07 & B \\
\hline Wool grass & 48 & 86.19 & $\mathrm{C}$ \\
\hline Soft rush & 48 & 85.45 & D \\
\hline \multicolumn{4}{|l|}{ Cattail } \\
\hline \multicolumn{4}{|l|}{ Periods (days) } \\
\hline $1(1-8)$ & 24 & 91.14 & A \\
\hline $2(9-17)$ & 24 & 88.42 & B \\
\hline $3(18-26)$ & 24 & 85.65 & $\mathrm{C}$ \\
\hline $4(27-35)$ & 24 & 80.94 & D \\
\hline $5(36-44)$ & 24 & 79.29 & E F \\
\hline $6(45-53)$ & 24 & 80.07 & DE \\
\hline $7(54-62)$ & 24 & 78.83 & $\mathrm{~F}$ \\
\hline $8(63-72)$ & 24 & 75.79 & $\mathrm{G}$ \\
\hline \multicolumn{4}{|l|}{ Concentration } \\
\hline Tolerance & 64 & 90.61 & $\mathrm{~B}$ \\
\hline Landfill & 64 & 63.02 & $\mathrm{C}$ \\
\hline \multicolumn{4}{|l|}{ Leachate } \\
\hline Control & & & \\
\hline
\end{tabular}

Means with the same letter are not significantly different from each other at a $95 \%$ confidence level.
Soil: The change in manganese concentrations in the soils are shown in Figure 5. The concentration of
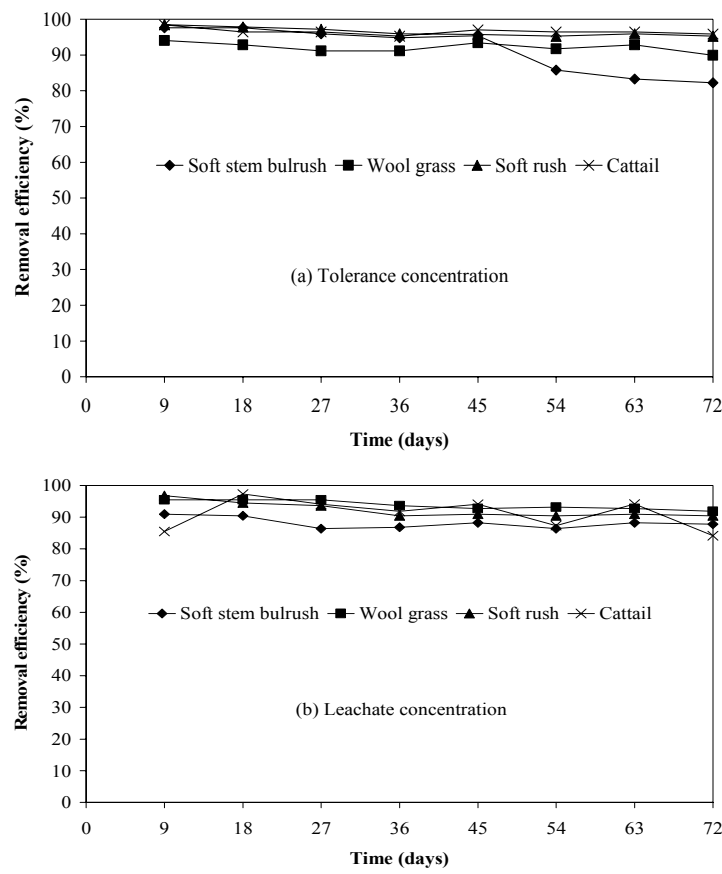

Fig. 4: Manganese removal efficiency trends for the four plants

manganese in the soils of soft stem bulrush, wool grass, soft rush and cattail increased to 639 and $1721 \mathrm{mg} / \mathrm{kg}$, to 645 and $1627 \mathrm{mg} / \mathrm{kg}$, to 635 and $1654 \mathrm{mg} / \mathrm{kg}$ and to 586 and $1603 \mathrm{mg} / \mathrm{kg}$ by the end of the experiment $(72$ days) in the compartments receiving the landfill leachate and tolerance concentration, respectively. These results showed the addition of manganese (from wastewater) to the soil by precipitation at average rates of 2.17 and $17.19 \mathrm{mg} / \mathrm{kg} /$ day, 2.11 and 15.75 $\mathrm{mg} / \mathrm{kg} / \mathrm{day}, 1.71$ and $15.86 \mathrm{mg} / \mathrm{kg} / \mathrm{day}$ and 1.17 and $15.29 \mathrm{mg} / \mathrm{kg}$ /day for soft stem bulrush, wool grass, soft rush and cattail in the compartments receiving landfill leachate and tolerance concentration, respectively.

A possible reason for an increase in manganese concentrations in the soil could be sedimentation of manganese precipitates and manganese bound to particulate matter. Eckhardt et al. ${ }^{[26]}$ conducted a study to determine the ability of a 2 cell, vegetated surface flow wetland to treat leachate from a landfill in New York and found that the concentrations of manganese in the sediment of the first and second cells increased over time and were 307 and $298 \mathrm{mg} / \mathrm{kg}$ after two years, respectively. Ye et al. ${ }^{[9]}$ conducted a study to determine the ability of a 4 cell, vegetated surface flow wetland to treat leachate from an electrical power station in 

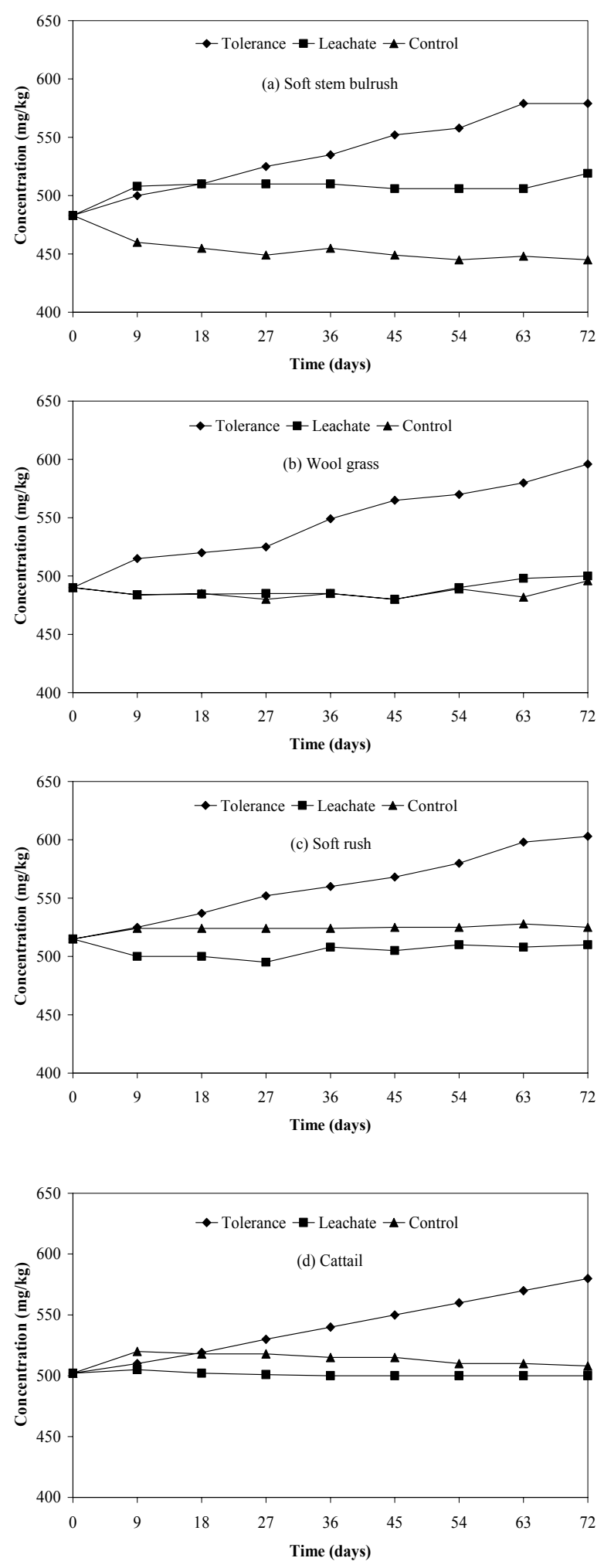

Fig. 5: Manganese concentrations in the soil
Pennsylvania and found that the average manganese concentrations increased over the two year study period and were $3310,1350,830$ and $872 \mathrm{mg} / \mathrm{kg}$ in the uppermost sediments of cells $1-4$, respectively. Ye et al. ${ }^{[27]}$ conducted a study to determine the ability of a 10 year old, 2 cell, vegetated surface flow wetland to treat leachate from an electrical utility in Alabama and found that average concentrations of manganese in the sediment from the two cells were in the range of 200 to $400 \mathrm{mg} / \mathrm{kg}$.

A possible reason for an increase in manganese concentrations in the soil could be sedimentation of manganese precipitates and manganese bound to particulate matter. Eckhardt et al. ${ }^{[26]}$ conducted a study to determine the ability of a 2 cell, vegetated surface flow wetland to treat leachate from a landfill in New York and found that the concentrations of manganese in the sediment of the first and second cells increased over time and were 307 and $298 \mathrm{mg} / \mathrm{kg}$ after two years, respectively. Ye et al. ${ }^{[9]}$ conducted a study to determine the ability of a 4 cell, vegetated surface flow wetland to treat leachate from an electrical power station in Pennsylvania and found that the average manganese concentrations increased over the two year study period and were 3310, 1350, 830 and $872 \mathrm{mg} / \mathrm{kg}$ in the uppermost sediments of cells $1-4$, respectively. Ye et al. ${ }^{[27]}$ conducted a study to determine the ability of a 10 year old, 2 cell, vegetated surface flow wetland to treat leachate from an electrical utility in Alabama and found that average concentrations of manganese in the sediment from the two cells were in the range of 200 to $400 \mathrm{mg} / \mathrm{kg}$.

The concentration of manganese in the soil of the control compartment of soft rush increased to 530 $\mathrm{mg} / \mathrm{kg}$ indicating addition of manganese to the soil at an average rate of $0.25 \mathrm{mg} / \mathrm{kg} /$ day while the concentration of manganese in the soil of the control compartments of soft stem bulrush, wool grass and cattail decreased to 454, 481 and $476 \mathrm{mg} / \mathrm{kg}$ indicating removal of manganese from the soil at average rates of $0.70,0.17$ and $0.36 \mathrm{mg} / \mathrm{kg} /$ day, respectively.

A possible reason for a decrease in the manganese concentrations in the soil of the control compartments for soft stem bulrush, wool grass and cattail could be uptake of the bioavailable fraction of manganese from the soil. The bioavailable manganese in the system is made of two portions: (a) the manganese in the water from fertilizers and reagents and (b) the manganese that naturally existed in the soil. Therefore, the total plant uptake of manganese may include that in water plus some of the bioavailable $\mathrm{Mn}$ in the soil. Due to the high affinity of plants for manganese, some plants in the 
compartments with low Mn concentrations (control and landfill leachate) utilized the bioavailable portion of $\mathrm{Mn}$ in the soil.

Plants: The concentrations of manganese in plant tissues of the four plants are shown in Figures $6-9$. The initial concentrations of manganese in the roots, leaves and flowers of soft stem bulrush were $62 \mathrm{mg} / \mathrm{kg}$, $84 \mathrm{mg} / \mathrm{kg}$ and $239 \mathrm{mg} / \mathrm{kg}$ which increased by the end of the experiment ( 72 days) to 140,148 and $156 \mathrm{mg} / \mathrm{kg}$, to 150,210 and $268 \mathrm{mg} / \mathrm{kg}$, and to 419,599 and 788 $\mathrm{mg} / \mathrm{kg}$ in the compartments receiving the control, landfill leachate and tolerance concentration, respectively. The initial concentrations of manganese in the roots, stems, leaves and flowers of wool grass were $39 \mathrm{mg} / \mathrm{kg}, 28 \mathrm{mg} / \mathrm{kg}, 46 \mathrm{mg} / \mathrm{kg}$ and $20 \mathrm{mg} / \mathrm{kg}$ which increased by the end of the experiment ( 72 days) to 63 , 81 and $90 \mathrm{mg} / \mathrm{kg}$, to 103,196 and $289 \mathrm{mg} / \mathrm{kg}$, to 148 , 170 and $191 \mathrm{mg} / \mathrm{kg}$, and 56,204 and $351 \mathrm{mg} / \mathrm{kg}$ in the compartments receiving the control, landfill leachate and tolerance concentration, respectively. The initial concentrations of manganese in the roots, leaves and flowers of soft rush were $65 \mathrm{mg} / \mathrm{kg}, 81 \mathrm{mg} / \mathrm{kg}$, and 275 $\mathrm{mg} / \mathrm{kg}$ which increased by the end of the experiment (72 days) to 97,157 and $217 \mathrm{mg} / \mathrm{kg}$, to 171,242 and $313 \mathrm{mg} / \mathrm{kg}$, and to 421,446 and $471 \mathrm{mg} / \mathrm{kg}$ in the compartments receiving the control, wetland influent and tolerance concentration, respectively. The initial concentration of manganese in the roots and leaves of cattail were $24 \mathrm{mg} / \mathrm{kg}$ and $250 \mathrm{mg} / \mathrm{kg}$ which increased by the end of the experiment ( 72 days) to 34,81 and $127 \mathrm{mg} / \mathrm{kg}$ and 730,757 and $783 \mathrm{mg} / \mathrm{kg}$ in the compartments receiving the control, wetland influent and tolerance concentrations, respectively. The results showed that the manganese concentration in the plant tissues is directly proportional to the initial manganese concentration in the wastewater (Table 5). Marschner ${ }^{[1]}$ stated that the Mn content of plants is not only affected by plant characteristics, but also by the pool of available $\mathrm{Mn}$ which is highly controlled by soil properties. Samecka-Cymerman and Kempers ${ }^{[28]}$ collected plant samples from 9 different impacted sites around a former open cut brown coal mine and found that the manganese concentration in the leaves of the various plant samples (Phyragmites australis, Potamogeton natans, Iris pseudoacorus, Juncus effusus, Drepanocladus aduncus, Juncus bulbosus, Phalaris arundinacea, Carex remota and Calamagrostis epigeios) increased with the increase of manganese concentration in the water. Kabata-Pendias and Pendias ${ }^{[29]}$ suggested that because Mn seems to be easily taken up by plants when it occurs in soluble
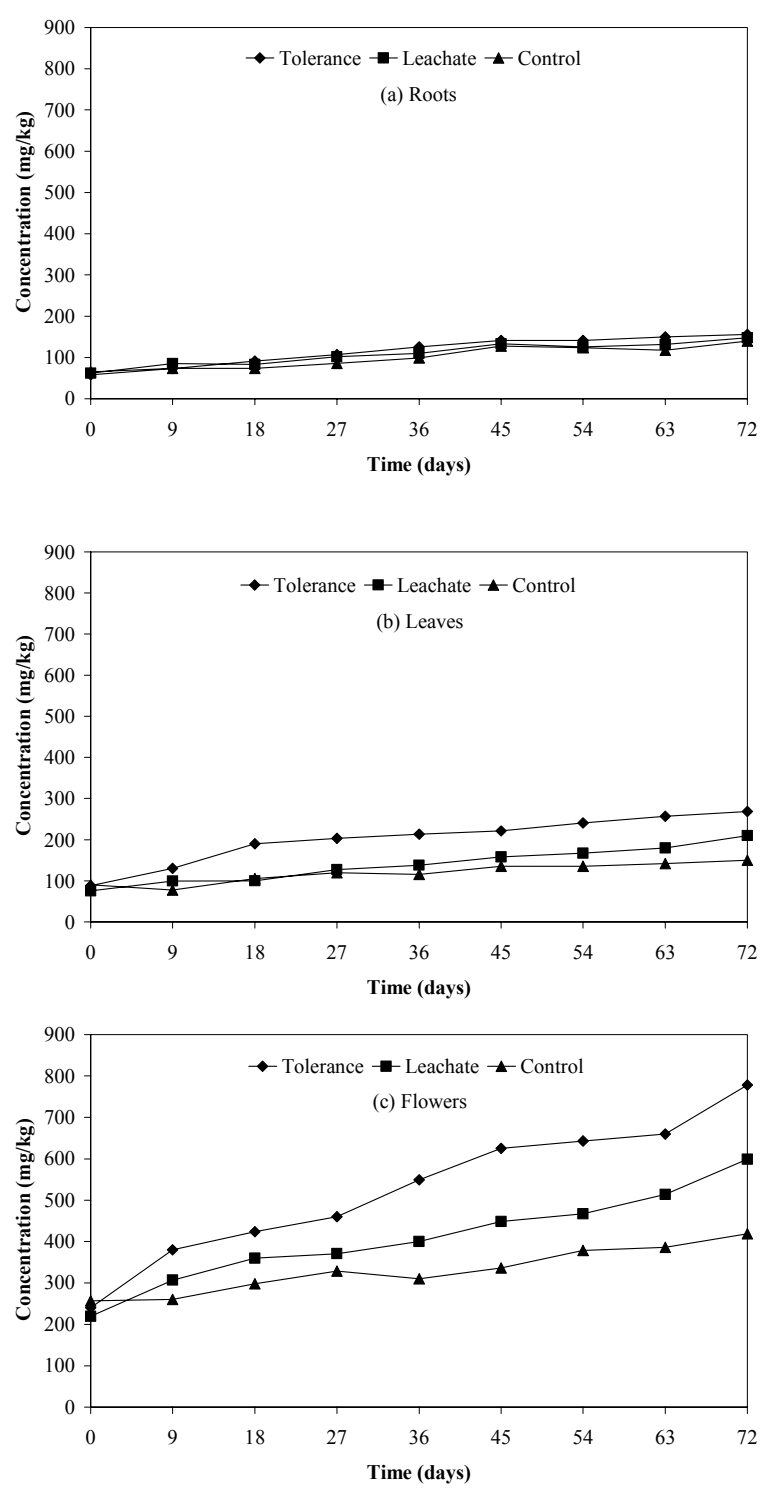

Fig. 6: Manganese concentrations in the various parts of the soft stem bulrush

forms in soils, the Mn content of plants should be a direct function of the soluble $\mathrm{Mn}$ pool in soils.

The highest amount of manganese accumulated in the total plant tissues was in soft stem bulrush with concentrations of 1202, 957 and $709 \mathrm{mg} / \mathrm{kg}$ and the lowest was in wool grass with concentrations of 921 , 649 and $370 \mathrm{mg} / \mathrm{kg}$ for the compartments receiving tolerance concentration, landfill leachate and control, respectively. The highest amount of manganese accumulated in the root tissues was in soft rush with concentrations of 217,157 and $97 \mathrm{mg} / \mathrm{kg}$ and the lowest 

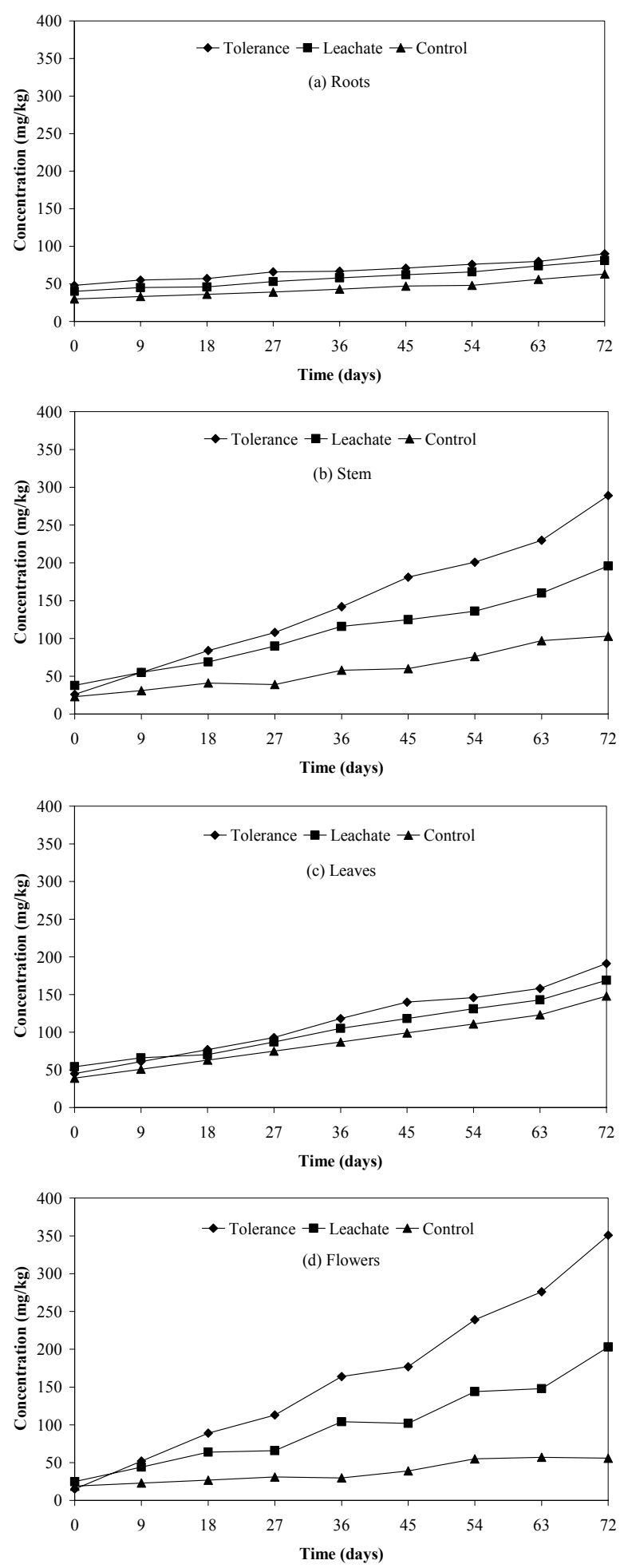

Fig. 7: Manganese concentrations in the various parts of the wool grass
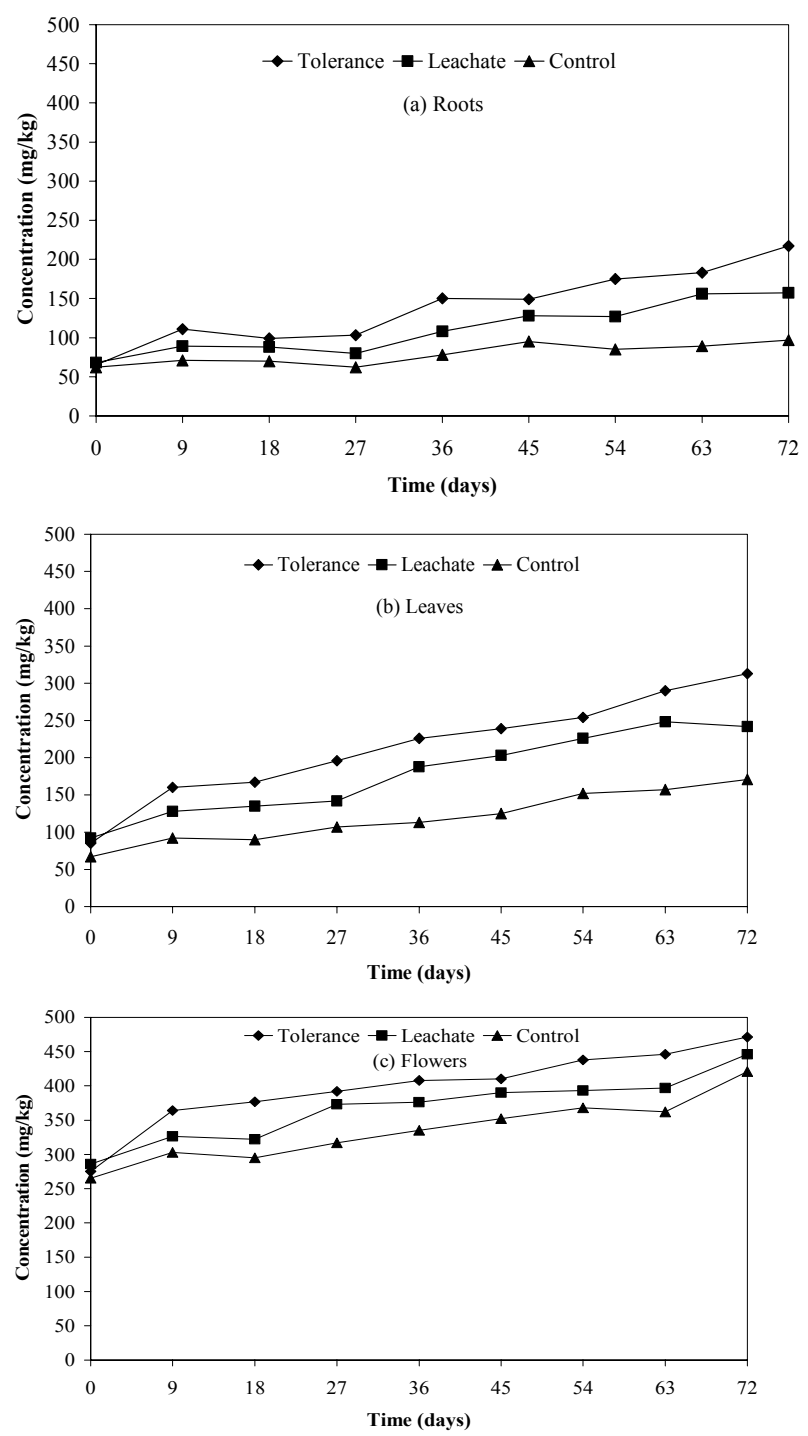

Fig. 8: Manganese concentration in the various parts of the soft rush

was in wool grass with concentrations of 90,81 and 63 $\mathrm{mg} / \mathrm{kg}$ for compartments receiving the tolerance concentration, landfill leachate and control, respectively. The highest amount of manganese accumulated in the leaves was in cattail with concentrations of 783,757 and $730 \mathrm{mg} / \mathrm{kg}$ and the lowest was in wool grass with concentrations of 191, 169 and $148 \mathrm{mg} / \mathrm{kg}$ in compartments receiving the tolerance concentration, landfill leachate and control, respectively. The highest amount of manganese accumulated in the flowers was in soft stem bulrush with concentrations of 778,599 and $419 \mathrm{mg} / \mathrm{kg}$ and the lowest was in wool grass with concentrations of 351 , 

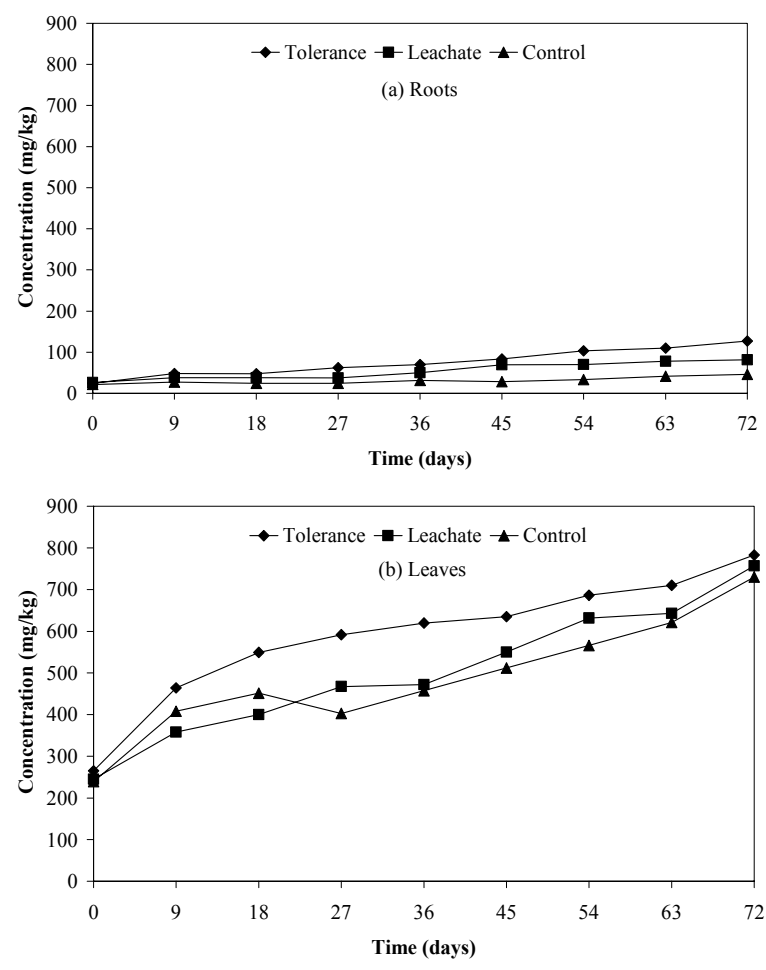

Fig. 9: Mn concentrations in the various parts of cattail

203 and $56 \mathrm{mg} / \mathrm{kg}$ in compartments receiving the tolerance concentration, landfill leachate and control, respectively.
Kabata-Pendias and Pendias ${ }^{[29]}$ reported that the Mn concentration fluctuates greatly within the plant parts and within the vegetative period. Resh ${ }^{[30]}$ stated that immobile elements such as Mn cannot be translocated from their original site of deposition to the actively growing region of the plant and a deficiency of an immobile element appears on young leaves on the upper portion of the plant. Page et al. ${ }^{[31]}$ demonstrated that ${ }^{54} \mathrm{Mn}$ remained in the oldest leaves of white lupin and was not transported to the younger leaves. Nable and Loneragan ${ }^{[32]}$ examined the mobility of manganese from old leaves during vegetative growth by following manganese redistribution in parts of subterranean clover plants. In plants transferred from nutrient solutions with $1 \mu \mathrm{M} \mathrm{Mn}^{2+}$ to solutions without $\mathrm{Mn}^{2+}$, there was no net loss of manganese from old leaves, although plants developed severe manganese deficiency symptoms in young leaves.

The ANOVA results (Table 6) showed that the plant type and the initial manganese concentration have significant effects on the plant uptake $(\mathrm{P}=0.0001)$. There were significant interactions $(P=0.0001)$ between the parameters. The results of Duncan's Multiple Range test (Table 7) showed that the four plants used in this study (soft stem bulrush, wool grass, soft rush and cattail) were significantly different from one another in their ability to accumulate manganese and the three levels of the initial manganese concentrations were significantly different from one another at a $95 \%$ confidence level.

Table 5: Sources of manganese assimilated by the plants

\begin{tabular}{|c|c|c|c|c|c|c|c|}
\hline \multirow{2}{*}{ Treatment } & \multirow{2}{*}{ Plant } & \multicolumn{2}{|c|}{ Total Uptake $^{+}$} & \multicolumn{2}{|c|}{ From Water } & \multicolumn{2}{|l|}{ From Soil } \\
\hline & & $(\mathrm{mg} / \mathrm{kg})$ & $(\mathrm{mg})^{++}$ & (mg) & $(\%)$ & $(\mathrm{mg} / \mathrm{kg})$ & $(\%)$ \\
\hline \multirow[t]{4}{*}{ Control } & Bulrush & 709 & $144.8(10.24)$ & $65.4(4.62)$ & 45.17 & $79.4(5.61)$ & 54.83 \\
\hline & Wool grass & 370 & $40.8(2.62)$ & $47.4(3.35)$ & 117.32 & $-6.6(0.47)$ & -17.32 \\
\hline & Soft rush & 689 & $131.4(9.29)$ & $70.2(4.96)$ & 53.42 & $61.2(4.33)$ & 46.58 \\
\hline & Cattail & 776 & $544.6(32.09)$ & $70.5(4.99)$ & 12.95 & $474.1(33.52)$ & 87.05 \\
\hline \multirow[t]{4}{*}{ Leachate } & Bulrush & 957 & $210.4(14.88)$ & $468.0(33.09)$ & 222.43 & $-257.6(18.21)$ & -122.43 \\
\hline & Wool grass & 649 & $52.5(4.12)$ & $497.5(35.17)$ & 947.61 & $-445.0(31.47)$ & -847.61 \\
\hline & Soft rush & 845 & $290.8(16.49)$ & $489.0(34.57)$ & 209.6 & $-255.8(18.09)$ & -109.64 \\
\hline & Cattail & 838 & $607.2(35.78)$ & $476.2(33.67)$ & 78.42 & $131.0(9.26)$ & 21.57 \\
\hline \multirow[t]{4}{*}{ Tolerance } & Bulrush & 1202 & $258.4(18.27)$ & $3387.0(239.49)$ & 1310.8 & $-3128.6(221.23)$ & -1210.8 \\
\hline & Wool grass & 921 & $81.5(4.09)$ & $3326.0(240.94)$ & 4081 & $-3338.0 \quad 236.03)$ & -4802.9 \\
\hline & Soft rush & 1001 & $372.6(26.34)$ & $3567.0(252.22)$ & 957.32 & $-3194.4(225.87)$ & 857.32 \\
\hline & Cattail & 910 & $678.8(43.63)$ & $3570.0(252.43)$ & 525.92 & $-2891.2(204.44)$ & -425.92 \\
\hline
\end{tabular}


Am. J. Applied Sci., 5 (4): 392-404, 2008

Table 6: Analysis of variance of the manganese accumulation in plant

\begin{tabular}{lrrrrc}
\multicolumn{1}{c}{ tissues } & \multicolumn{1}{c}{ MS } & \multicolumn{1}{c}{ F- } \\
Source & DF & SS & P \\
& & & & Value & \\
\hline Total & 23 & 1192725.75 & 51857.64 & & \\
Model & 11 & 118676.12 & 107887.38 & 217.05 & 0.0001 \\
$\quad$ Plant Type (P) & 2 & 74287.28 & 37143.64 & 74.73 & 0.0001 \\
$\quad$ Concentration & 3 & 1086547.82 & & 728.66 & 0.0001 \\
(C) & & & 362182.61 & & \\
$\quad$ P x & 6 & 25926.03 & 4321.00 & 8.69 & 0.0008 \\
Error & 12 & 5964.75 & & & \\
\hline $\mathrm{R}^{2} \quad=0.99$ & & & & & \\
$\mathrm{CV} \quad=7.65 \%$ & & & & &
\end{tabular}

Table 7: Differences among the plant type and initial manganese

\begin{tabular}{|c|c|c|c|}
\hline Parameter & $\begin{array}{c}\text { Number of } \\
\text { Observations }\end{array}$ & $\begin{array}{c}\text { Total Mn in } \\
\text { Plant Tissues }\end{array}$ & $\begin{array}{c}\text { Duncan } \\
\text { Grouping }\end{array}$ \\
\hline \multicolumn{4}{|l|}{ Plant Type } \\
\hline Soft stem bulrush & 6 & 214.78 & A \\
\hline Wool grass & 6 & 56.82 & B \\
\hline Soft rush & 6 & 258.06 & $\mathrm{C}$ \\
\hline Cattail & 6 & 636.48 & $\mathrm{D}$ \\
\hline \multicolumn{4}{|l|}{$\mathrm{Mn}$} \\
\hline \multicolumn{4}{|l|}{ Concentration $(\mathrm{mg} / \mathrm{L})$} \\
\hline Tolerance & 8 & 361.16 & A \\
\hline Wetland Influent & 8 & 288.45 & B \\
\hline Control & 8 & 224.99 & $\mathrm{C}$ \\
\hline
\end{tabular}
other at a $95 \%$ confidence level.

Table 8: Manganese uptake and distribution in plant tissues

\begin{tabular}{|c|c|c|c|c|c|c|}
\hline & \multirow{2}{*}{$\begin{array}{c}\text { Total Uptake } \\
\text { (mg) }\end{array}$} & \multicolumn{4}{|c|}{ Manganese Distribution } & \multirow{2}{*}{$\begin{array}{c}\text { Translocation } \\
\text { Factor }^{+}\end{array}$} \\
\hline & & $\begin{array}{l}\text { Roots } \\
(\mathrm{mg})\end{array}$ & $\begin{array}{l}\text { Stem } \\
(\mathrm{mg})\end{array}$ & $\begin{array}{c}\text { Leaves } \\
(\mathrm{mg})\end{array}$ & $\begin{array}{c}\text { Flowers } \\
(\mathrm{mg})\end{array}$ & \\
\hline \multicolumn{7}{|l|}{ Soft stem bulrush } \\
\hline Tolerance & $258.4(18.27)$ & $137.6(9.73)$ & NA & $108.0(7.64)$ & $12.9(0.91)$ & 0.87 \\
\hline Landfill Leachate & $210(14.88)$ & $120.8(8.54)$ & NA & $80.8(5.71)$ & $9.0(0.64)$ & 0.74 \\
\hline Control & $144.8(10.24)$ & $119.0(5.4)$ & NA & $58.5(3.89)$ & $6.5(0.23)$ & 0.54 \\
\hline \multicolumn{7}{|l|}{ Wool grass } \\
\hline Tolerance & $81.5(4.09)$ & $19.5(0.17)$ & $14.7(1.04)$ & $35.0(2.47)$ & $8.0(0.57)$ & 2.95 \\
\hline Landfill Leachate & $52.5(4.12)$ & $11.4(0.81)$ & $8.8(0.62)$ & $27.8(1.96)$ & $4.2(0.31)$ & 3.57 \\
\hline Control & $40.8(2.62)$ & $9.5(1.20)$ & $4.9(0.53)$ & $25.16(2.12)$ & $1.2(0.12)$ & 3.29 \\
\hline \multicolumn{7}{|l|}{ Soft rush } \\
\hline Tolerance & $372.6(26.34)$ & $182.4(12.89)$ & NA & $182.4(12.0)$ & $7.6(0.53)$ & 1.04 \\
\hline Landfill Leachate & $290.8(16.49)$ & $107.0(7.55)$ & NA & $120.0(8.49)$ & $64.0(4.52)$ & 1.72 \\
\hline Control & $131.4(9.29)$ & $46.3(4.28)$ & NA & $92.5(7.89)$ & $6.3(0.31)$ & 2.13 \\
\hline \multicolumn{7}{|l|}{ Cattail } \\
\hline Tolerance & $678.8(43.63)$ & $140.1(9.91)$ & NA & $538.7(38.09)$ & NA & 3.85 \\
\hline Landfill Leachate & $607.2(35.78)$ & $74.8(5.28)$ & NA & $532.5(37.65)$ & NA & 7.11 \\
\hline Control & $544.6(32.09)$ & $46.0(1.02)$ & NA & $503.7(10.23)$ & NA & 10.95 \\
\hline
\end{tabular}

Peltier, et al. ${ }^{[33]}$ collected common reeds (Phragmites) grown along the edge of the waterline of a metalcontaminated wetland having manganese concentration of $0.96 \mathrm{mg} / \mathrm{L}$ and found that the concentrations of manganese were 1027,138 and $46 \mathrm{mg} / \mathrm{kg}$ in roots, stem and leaves, respectively. Sanchez et al. ${ }^{[34]}$ sampled aquatic moss (Brachythecium rivulare), soft rush (Juncus effusus), and board leaf cattail (Typha latifolia) from different sites near an old lead-zinc mine and found the manganese concentrations in the leaves were 1850,345 and $1950 \mathrm{mg} / \mathrm{kg}$ for moss, soft rush and board leaf cattail, respectively. It appears from the results obtained from the present study that the four plants used were somewhat inferior accumulators of manganese compared to the plants used in other studies.

The leaves accumulated significantly greater concentrations of manganese than the roots (Table 8), indicating high plant availability of the substrate metal. 
Generally, Mn is known to be taken up and translocated within plants rapidly. Manganese is reported to occur in plant fluids and extracts mainly as free cationic forms and is likely to be transported as $\mathrm{Mn}^{2+}$ but redistribution of $\mathrm{Mn}$ in the phloem is very limited and may depend on the plant species and developmental stage ${ }^{[31]}$. However, its complexing compounds with organic molecules of 1000 to 5000 molecular weights have been found in phloem exudates ${ }^{[1]}$. Van Goor and Wiersma ${ }^{[35]}$ reported a much lower $\mathrm{Mn}$ concentration in phloem exudates than in leaf tissues and concluded that a slight transport of $\mathrm{Mn}$ through the phloem vessels is responsible for the low concentration of $\mathrm{Mn}$ in fruits, seeds, and storage roots.

\section{CONCLUSIONS}

The overall manganese removal efficiencies of the system during the first period were 97.66, 94.09, 98.51 and $98.44 \%$ and $90.94,95.47,96.83$ and $85.51 \%$ and $92.65,75.55,97.56$ and $75.55 \%$ which decreased to 82.22, 89.94, 95.26 and 95.85 \% and 87.78, 91.85, 90.49 and $84.16 \%$ and $38.88,61.61,31.54$ and $71.64 \%$ by the end (after 72 days) of the experiment for soft stem bulrush, wool grass, soft rush and cattail in the compartments receiving tolerance concentration landfill leachate and the control, respectively. The removal of manganese was a function of the initial Mn concentration and the higher the initial concentration the higher the removal efficiency. The results showed the addition of manganese (from wastewater) to the soil by precipitation at average rates of 2.17 and 17.19 $\mathrm{mg} / \mathrm{kg} / \mathrm{day}, 2.11$ and $15.75 \mathrm{mg} / \mathrm{kg} / \mathrm{day}, 1.71$ and 15.86 $\mathrm{mg} / \mathrm{kg} /$ day and 1.17 and $15.29 \mathrm{mg} / \mathrm{kg} /$ day for soft stem bulrush, wool grass, soft rush and cattail in the compartments receiving landfill leachate and tolerance concentration, respectively. The concentration of manganese in the soil of the control compartment of soft rush increased at an average rate of $0.25 \mathrm{mg} / \mathrm{kg} /$ day while the concentration of manganese in the soil of the control compartments of soft stem bulrush, wool grass and cattail decreased at average rates of $0.70,0.17$ and $0.36 \mathrm{mg} / \mathrm{kg} /$ day, respectively. The highest amount of manganese accumulated in the total plant tissues was in soft stem bulrush with concentrations of 1202, 957 and $709 \mathrm{mg} / \mathrm{kg}$ and the lowest was in wool grass with concentrations of 921,649 and $370 \mathrm{mg} / \mathrm{kg}$ for the compartments receiving tolerance concentration, landfill leachate and control, respectively.

\section{ACKNOWLEDGEMENTS}

This research was funded by the ELJB Foundation of Montreal and Environment Canada.

\section{REFERENCES}

1. Marschner, H. 1995. Mineral Nutrition of Higher Plants $2^{\text {nd }}$ edition. Academic Press, New York, NY.
2. Langille, W. M. and K. S. MacLean. 1976. Some essential nutrient elements in forest plants as related to species, plant part, season and location. Plant and Soil, 45: 17-26.

3. Hanna, W. J. and C. L. Grant. 1962. Spectrochemical analysis of the foliage of certain trees and ornamentals for 23 elements. Bulletin of the Torrey Botanical Club, 89: 293-302.

4. Baker, A. J. M. and R. R. Brooks. 1989. Terrestrial higher plants which hyperaccumulate metallic elements- A review of their distribution, ecology and phytochemistry. Biorecovery, 1: 81-126.

5. Ernst, W. H.O., J. A. C. Verkleji and H. Schat. 1992. Metal tolerance in plants. Acta Physiologica et Pharmacologica Neerlandica, 41: 229-248.

6. Hall, J. L. 2002. Cellular mechanisms for heavy metal detoxification and tolerance. Journal of Experimental Botany, 53 (366): 1-11.

7. Memon, A. R., D. Aktoprakligil, A. Ozdemir and A. Vertii. 2001. Heavy metal accumulation and detoxification mechanisms in plants. Turkish Journal of Botany, 25:111-121.

8. Dunbabin, J. S. and K. H. Bowmer. 1992. Potential use of constructed wetlands for treatment of industrial wastewaters containing metals. The Science of the Total Environment, 111: 151-168.

9. Ye, Z. H., S. N. Whiting, Z.-Q. Lin, C. M. Lytle, J. H. Qian and N. Terry. 2001. Removal and distribution of iron, manganese, cobalt, and nickel within a Pennsylvania constructed wetland treating coal combustion by-product leachate. Journal of Environmental Quality, 30:1464-1473.

10. Hammer, D. A. and R. K. Bastian. 1993. Wetlands ecosystems: natural water purifiers. In: Hammer, D. A. (editor). Constructed Wetlands for Wastewater Treatment: Municipal, Industrial and Agricultural. Lewis Publishers, Boca Raton, Florida. p. 5-19.

11. Kindscher, K., A. Fraser, M. E. Jakubauskas and D. M. Debinski. 1998. Identifying wetland meadows in Grand Teton National Park using remote sensing and average wetland values. Wetlands Ecology and Management, 5: 265-273.

12. Mills, J. 2003. Greenhouse Manager, Department of Biology. Dalhousie University, Halifax, Nova Scotia. (Personal Communication).

13. Galbrand, C. 2004. Naturalized treatment wetlands for contaminant removal: A case study of the Burnside engineering wetland for treatment of landfill leachate. Master of Environmental Studies. Dalhousie University, Halifax, Nova Scotia.

14. Ghaly, A. E. and R. Cote. 2001. Engineered Wetland Technology for Treatment of Industrial Park Contaminants, Technical Report, Dalhousie University, Halifax, Nova Scotia. 
15. Kamal, M., A. E. Ghaly, N. Mahmoud and R. Cote. 2004. Phytoaccumulation of heavy metals by aquatic plants. Environment International, 8: 10291039.

16. Groudeva, V. I., S. N. Groudev and A. S. Doycheva. Bioremediation of waters contaminated with crude oil and toxic heavy metals. 2001. International Journal of Mineral Processing, 62 (14): 293-299.

17. Mitchell, L. K. and A D. Karathanasis. 1995. Treatment of metal-chloride-enriched wastewater by simulated constructed wetlands. Environmental Geochemistry and Health, 17, 199-126.

18. Brodie, G. A. 1993. Staged, aerobic constructed wetlands to treat acid drainage: Case history of Fabius Impoundment 1 and Overview of the Tennessee Valley Authority's Program. In: Moshiri, G. A. (editor). Constructed Wetlands for Waster Quality Improvement. Lewis Publishers, Boca Raton, Florida.

19. Stillings, L. L., J. J. Gryta and E. A. Ronning. 1988. Iron and manganese removal in a Typhadominated wetland during ten months following wetland construction. Mine drainage and surface mine reclamation. United States Bureau of Mines, Pittsburgh, PA. p. 317-324.

20. Fennessy, M. S., and W. J. Mitsch. 1989. Treating coalmine drainage with an artificial wetland. Research Journal of the Water Pollution Control Federation, 61:1691-1701.

21. Hedin, R. S. 1989. Treatment of coal mine drainage with constructed wetlands. In: Majumdar, S. K. (editor). Wetlands Ecology and Conservation: Emphasis in Pennsylvania. The Pennsylvania. Academy of Science, Easton, PA. p. 349-362.

22. Skousen, J. A., K. Sexstone, J. Garbutt and J. Sencindiver. 1994. Acid mine drainage treatment with wetlands and anoxic limestone drains. In: Kent, D. M. (editor). Applied Wetland Science and Technology. Lewis Publishing, Boca Raton, FL. p. 263-281.

23. Stark, L. R., F. M. Williams, S. E. Stevens and D. P. Eddy. 1994. Metal removal in wetland treatment systems. Proceedings International Land Reclamation and Mine Drainage Conference. Bureau of Mines, United States Department of Interior, Pittsburgh, PA. p. 89-98. 24-29 April.

24. Skousen, J. K., A. Rose, G. Geidel, J. Foreman, R. Evans, and W. Heller. 1998. A Handbook of Technologies for Avoidance and Remediation of Acid Mine Drainage. National Mine Land Reclamation Center, Morgantown, WV.
25. BCMELP. 2001. Ambient Water Quality Guidelines for Manganese. British Columbia Ministry of Environment, Lands and Parks, Vancouver, British Columbia. Retrieved September 14, 2002, from http://wlapwww.gov.bc.ca/wat/wq/BCguidelines/m anganese.html

26. Eckhardt, D. A. V., J. M. Surface and J. H. Peverly. 1999. A constructed wetland system for treatment of landfill leachate, Monroe County, New York. In: Mulamoottil, G., E. A. McBean and F. Rovers (editors). Constructed Wetlands for the Treatment of Landfill Leachates. Lewis Publishers, Boca Raton, Florida. p. 205-222.

27. Ye, Z. H., S. N Whiting, J. H. Qian, C. M. Lytle, Z.-Q. Lin and N. Terry. 2001b. Trace element removal from coal ash leachate by a 10 -year-old constructed wetland. Journal of Environmental Quality, 30 (5): 1710-1719.

28. Samecka-Cymerman, A. and A. J. Kempers. 2001. Bioindication of heavy metals with aquatic macrophytes: the case of a stream polluted with power plant sewages in Poland. Journal of Toxicology and Environmental Health-Part A, 62(1):57-67.

29. Kabata-Pendias, A. and H. Pendias. 1992. Trace Elements in Soils and Plants. $2^{\text {nd }}$ edition. CRC Press, Boca Raton, Florida.

30. Resh, H. M. 2004. Hydroponic Food Production. Newconcept Press, Inc., Mahwah, NJ.

31. Page V., L. Weisskopf and U. Feller. 2006. Heavy metals in white lupin: uptake, root to shoot transfer and redistribution within the plant. New Phytologist, 171: 329-341.

32. Nable, R. O. and J. F. Loneragan. 1984. Translocation of manganese in subterranean clover (Trifolium subterraneum L.) I. Redistribution during vegetative growth. Australian Journal of Plant Physiology, 11(2): $101-111$.

33. Peltier, E. F., S. M. Webb and J-F. Gaillard. 2003. Zinc and lead sequestration in an impacted wetland. Advances in Environmental Research, 8: 103.122 .

34. Sanchez, J., M. C. Vaquero and I. Legorburu. 1994. Metal pollution from old lead-zinc mine works: Biota and sediment from Oiartzun Valle. Environmental Technology, 15:1069-1076.

35. Van Goor, B. J. and D. Wiersma. 1974. Redistribution of potassium, calcium, magnesium and manganese in the plant. Physiologia Plantarum, 31 (3): 163-168. 